\title{
How to not lose the track: tail-head linkage as a mechanism for maintaining cohesion of spatial information in Dâw narratives
}

\section{Como não perder o caminho: tail-head linkage como mecanismo de manter coesão de informação espacial em narrativas Dâw}

\author{
Karolin Obert (1D \\ University of Texas at Austin. Austin, Estados Unidos
}

\begin{abstract}
References to landscape and places are central in traditional narratives by speakers of Dâw (Naduhup, Brazilian Amazon). This emphasis on spatial reference is primarily established through locative adverbial clauses that are often repeated throughout the discourse. Their function is to relate an event to a place, establish reference to locative information mentioned earlier in discourse, and provide cohesion when pre-posed to the main clause. In this syntactic position, they act as bridges connecting sentences and paragraphs by referring to antecedent context. Locative adverbial clauses in clause-initial position are interesting in Dâw because they can occur as exact replicas of a locative adverbial clause that was postposed to the main clause of the antecedent sentence. This strategy has been described in the literature as tail-head linkage. Its central function is to maintain coherence among participants and events along subsequent sentences in discourse and to ensure that the interlocutor is able to track the numerous locations mentioned in the narrative. This paper explores the functional and formal properties of tail-head linkage by focusing on locative adverbial clauses in Dâw, and contributes to the understanding of how processes of subordination can be responsible for tracking spatial information in the discourse of Dâw speakers.
\end{abstract}

Keywords: Naduhup family. Locative adverbial clauses. Subordination. Tail-head linkage. Space. Discourse.

Resumo: Referências a paisagens e lugares são elementos centrais nas narrativas tradicionais de falantes da língua Dâw (Naduhup, Amazônia brasileira). Essa ênfase na referência espacial é estabelecida principalmente por meio de orações adverbiais locativas que são frequentemente repetidas ao longo do discurso. Sua função é relacionar um evento a um lugar, estabelecer referência à informação locativa mencionada anteriormente no discurso e fornecer coesão quando pré-posta à oração principal. Nessa posição sintática, eles funcionam como pontes conectando sentenças e parágrafos referindo-se ao contexto antecedente. Orações adverbiais locativas na posição inicial da cláusula são interessantes em Dâw porque podem ocorrer como réplicas exatas de uma cláusula adverbial locativa que foi posposta à cláusula principal da sentença antecedente. Essa estratégia tem sido descrita na literatura como tail-head linkage. Sua função central é manter a coerência entre os participantes e eventos ao longo das frases subsequentes do discurso e garantir que o interlocutor consiga rastrear os vários locais mencionados ao longo da narrativa. Este artigo explora as propriedades funcionais e formais de estruturas tail-head linkage com ênfase nas orações adverbiais locativas em Dâw, contribuindo, assim, para o entendimento de como os processos de subordinação podem ser responsáveis para rastrear informações espaciais no discurso na língua Dâw.

Palavras-chave: Família linguística Naduhup. Cláusulas adverbiais locativas. Subordinação. Tail-head linkage. Espaço. Discurso.

Obert, K. (2021). How to not lose the track: tail-head linkage as a mechanism for maintaining cohesion of spatial information in Dâw narratives. Boletim do Museu Paraense Emílio Goeldi. Ciências Humanas, 16(3), e20200100. doi: 10.1590/2178-2547-BGOELDI-2020-0100 Autora para correspondência: Karolin Obert. The College of Liberal Arts. The University of Texas at Austin 116 Inner Campus Dr. Stop G6000, Austin 78712-1139, Estados Unidos (karolinobert@utexas.edu).

Recebido em 13/05/2021

Aprovado em 25/06/2021

Responsabilidade editorial: Adam Singerman

(cc) (i)

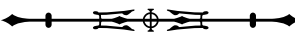




\section{INTRODUCTION}

Repetition is a recurrent element of storytelling;' it helps the listeners keep track of actors and events. Referring to places is also a common feature of narratives; it is typically employed by storytellers at the onset of a narrative to set the stage and even to foreshadow the type of a story to be told (e.g. Dingemanse et al., 2017). In this work, I present data from Dâw (Naduhup family), a small foraging-oriented group of northwestern Brazil (ISO 639-3:kwa), whose speakers, and in particular senior storytellers, show a particular approach to these standards. First, references to place are found throughout Dâw narratives in the form of parallelistic repetitions as exemplified in (1a-b); that is, they are not restricted to the onset of the story alone but form an underlying chain of interlocking place-references. ${ }^{2}$ Second, the repeated elements in Dâw narratives show a heavy emphasis on chunks that establish 'place-reference'.
daad rid baax dâw-â' rid
Marié.river LOC emerge dâw.people-FOC LOC
'At the Marié river is where the Dâw people emerged.'

$\begin{array}{lllllll}\text { [baax } & \text { dâw-â' } & \text { rid] } & \text { dâw-ẽumy' } & \text { nũux } & \text { wuum dâr } \\ \text { emerge } & \text { dâw.people-FOC } & \text { LOC } & \text { dâw.people-DOM } & \text { curupira } & \text { drown } & \text { AGTV }\end{array}$

'Where there Dâw people emerged, the curupira (forest spirit) drowned them.'

By understanding a narrative both as a communicative act and as a way of transmitting collective and individual memories as well as knowledge (see Sherzer, 1987; Sugiyama, 2001; Stenzel \& Franchetto, 2017), we can understand the transmission of spatial knowledge as one central function of Dâw narratives. This raises the question: through which linguistic devices do Dâw storytellers successfully achieve the transmission of spatial information? Sherzer (1987, p. 306), who describes discourse as "creator and recreator, and transmitter of culture" as well, answers this question by describing discourse as 'an embodiment of language' and therefore sees grammar as a set of potential devices for the mediation of this knowledge.

In that sense, and as outlined above, one specific and straightforward grammatical resource in Dâw narratives is the pervasive repetition of place references throughout narratives. In grammatical terms, such movements in Dâw correspond to a syntactic phenomenon known in the literature as 'tail-head linkage': a clause-connecting strategy that employs the verbatim repetition of the predicate from the last clause, i.e. 'the tail-clause', which is fully or partially repeated in the first clause of the adjacent sentence (Guillaume, 2011, p. 111). Its central function in narratives has been described as contributing to the maintenance of event and participant coherence; to background/foreground information or indicate temporal sequence, among other functions (e.g. Guillaume, 2011; Stenzel, 2016; Aikhenvald, 2019).

A typologically intriguing fact about tail-head linkage in Dâw is that the repetition of clauses is restricted to "locative adverbial clauses' that can occur as exact replicas of a postposed adverbial clause at the beginning of the following clause. This mechanism in Dâw can be understood as a process of subordination that is responsible for tracking spatial information

In this article, I follow Sugiyama (2001, p. 225) terminological suggestion to understand both 'narrative' and 'storytelling' as a form of 'oral performance' that goes back to the ability to tell stories. Both are best understood as a form of discourse that, following Sherzer (1987, p. 296), is a "level or component of language use, related but distinct from grammar" and that is situated at the interface between language and culture. In other words, both narrative and storytelling are specific verbally facets of discourse in natural usage contexts within a given culture. They display specific grammatical structures and cultural meanings that make them differ from other types of discourse.

2 Note that examples throughout this work marked with number and letters (1a; $1 \mathrm{~b}$; $1 \mathrm{c}$ etc.) make reference to consecutive lines in the respective narrative.

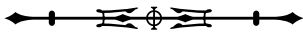


in narratives by maintaining coherence between events tied to places as the discourse develops, and helping the listener track the numerous locations named in the narrative. It is therefore a prime source of verbal artistry that functions much like a 'walking stick' throughout a narrative, anchoring the events to the real world, that is, to the Dâw people's landscape. This anchoring can be best visualized by mapping the repeated clause chunks of Dâw narratives onto the Dâw territory. As such, place-references function as imprints in the local geography mirroring the path of the storyline.

This work investigates the mechanism of tail-head linkage as a syntactic process of subordination as a key aspect of the grammar of spatial discourse in Dâw, a highly endangered language of Northwest Amazonia. More specifically, it addresses the question of how the repetition of locative adverbial clauses throughout Dâw narratives can be an effective way of emphasizing and successfully transmitting spatial information to the interlocutor. ${ }^{3}$

The paper is organized as follows. First, I provide a typologically informed overview of what we already know about tail-head linkage from the literature in order to see how Dâw conforms to or deviates from the existing generalizations. I then introduce the Dâw people and their language to the audience. In this section, I also summarize the general characteristics of subordination and explore the form and function of locative adverbial clauses in Dâw. Subsequently, I explore the formal and functional properties of tail-head linkage in Dâw. The observation of such a concrete grammatical strategy in the light of discourse and communicative needs of a given culture can bring us closer to a more holistic understanding of possible relationships between language and culture as pointed out by Sherzer (1987, p. 296). The final section concludes with some implications for the typology of tail-head linkages, the syntax of subordination in Dâw, and the role of discourse in syntactic structure.

\section{WHAT DO WE KNOW ABOUT TAIL-HEAD LINKAGE?}

There is a consensus in the existing literature in describing tail-head linkage as a clause combining strategy with the function of ensuring referential and event coherence in narratives through the verbatim repetition of the verbal predicate at the beginning of the adjacent sentence. However, case studies in individual languages have revealed significant variation in form that can be partially motivated by the typological profile of a language (e.g. De Vries, 2005; Seifart, 2010). In this section, I provide a brief overview of the formal and functional properties of tail-head linkage as described in the literature, in order to establish an underlying working definition of the phenomena as necessary background for discussing tail-head linkage in Dâw, specifically.

The theoretical concept of tail-head linkage was initially introduced in the field of linguistics by descriptions of languages of the Philippines (see Longacre, 1968), Papua New Guinea (see Grimes, 1972), and South America (see Stout \& Thomson, 1971), but such phenomena have subsequently been described in a wide variety of languages from other parts of the world. ${ }^{4}$ Authors refer to this strategy with different terms such as 'overlay' (Grimes, 1972); 'backgrounded repetition' (McKay, 2008); 'bridging linkage' (Aikhenvald, 2019), 'recapitulative linkage' (Guérin \& Aiton, 2019), and 'tail-head linkage' (De Vries, 2005; Guillaume, 2011), among others.

\footnotetext{
All the data from this work comes from narratives recorded with nine Dâw storytellers during several language documentation projects conducted between 2013 - present. Due to limitations of space, note that entire narratives can be accessed in the Dâw collection at AILLA (see The Archive of the Indigenous Languages of Latin America, n.d.). For a fully glossed and commented narrative, I recommend Obert et al. (2019).

4 See Guillaume (2011, p. 111) for an overview of languages showing tail-head linkage and Guérin and Aiton (2019) recently edited 'work on bridging constructions', which brings together new perspectives on similar constructions on a diversity of languages from different parts of the world.
}

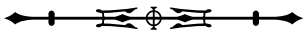


Despite this terminological variety, most authors agree upon some core formal features of such constructions, especially with respect to the position of the clauses; i.e. the 'tail-clause'5 occurs repeated as the first clause, the 'head-clause', in the subsequent chain (De Vries, 2005, p. 363). This generalization is schematized in the following template (adapted from Guérin \& Aiton, 2019, p. 3).

$$
\left.[\ldots[\text { tail-clause }]]_{\text {discursive unit } 1}[\text { head-clause }] \ldots\right]_{\text {discursive unit } 2}
$$

This template indicates that tail-clause and head-clause are in adjacent position, which is cross-linguistically common. However, Guérin and Aiton (2019, p. 6) provide evidence through an example from Jingulu (a non-Pama-Nyungan language, citing Pensalfini (2015)) that the tail-clause and head-clause may also be intervened by another clause.

For it to be considered a tail-head linkage, there must be content repeated from the tail-clause in the head-clause. An indispensable element is at least the verb/predicate as Guillaume (2011, p. 111) states. Thus, languages provide replicas with differing degrees of exactness in the repetition, i.e. the realization of arguments and obliques can, for example, be optional (Guillaume, 2011, p. 111). Example (2a-b) from Wambon (Papua New Guinea); De Vries (2005, p. 373) shows such a case where the adverbial element 'afternoon' has been omitted in the head-clause.

\begin{tabular}{|c|c|c|c|c|c|}
\hline $\begin{array}{l}\text { Sanopkuniv-eve } \\
\text { tuesday-that }\end{array}$ & $\begin{array}{l}\text { ilo } \\
\text { go.down:ss }\end{array}$ & $\begin{array}{l}\text { nggapmo-kndevan-o } \\
\text { cut-1PL:PRS-CONN }\end{array}$ & $\begin{array}{l}\text { ko } \\
\text { go:SS }\end{array}$ & $\begin{array}{l}\text { alipke-lo } \\
\text { afternoon-sS }\end{array}$ & $\begin{array}{l}\text { ndave-levambo } \\
\text { return-1PL:PST }\end{array}$ \\
\hline
\end{tabular}

\section{ndano la-levambon-o...}

return:Ss sleep-1PL:PST-CONN

'Having returned, we slept and...'

[Wambon, Papua New Guinea; De Vries, 2005, p. 373]

Furthermore, some languages display a specific type of this clause-linking strategy known as 'summary-head linkage' in which the predicate from the tail-clause is substituted as in examples (3a-b) from Tariana (Arawak; Aikhenvald, 2019, p. 462) or completed by a more generic verb as shown in example (3a-3b) from Kotiria (East-Tukano; Stenzel, 2016, p. 438). Those generic verbs usually correspond to 'do', 'be' or 'say' in the respective language, as Guillaume points out (2011, p. 111). In the Kotiria example, the tail-clause from (4a) is repeated at the beginning of the subsequent sentence in (4b) and co-occurs with the generic 'do' verb 'yoa' in order to indicate paragraph-level boundaries (cf. Stenzel, 2016, p. 438). ${ }^{6}$ To boot, Seifart (2010, p. 906) directs attention to the fact that the choice between repeating the same verb and a generic verb can have differences related to explicitness of information.

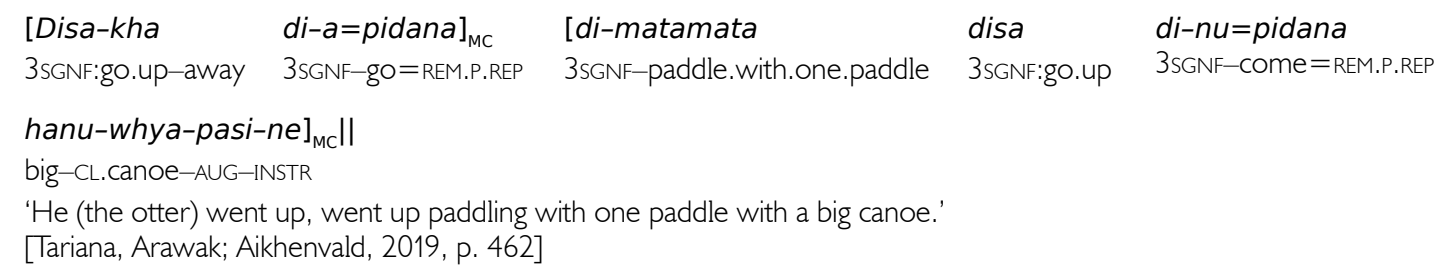

5 Both Aikhenvald (2019) and Guérin and Aiton (2019) use the terms 'reference' 'clause and bridging clause' in order to substitute the terms 'tail-clause' and 'head-clause'. Both terminologies show equivalent formal and functional behaviors. However, for this work I adapt the latter terminology.

6 For this work, I understand 'paragraph' as a component of discourse carrying episodes corresponding to the macro-structural components of a narrative (exposition; development; developing conflict; climax; result, and conclusion) (see Chafe, 2001).

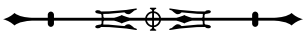


(3b)
[kay di-ni $\uparrow[$ Pause $]]_{\text {SUM.CL }}$
[tuki di-kapuku
disa
$d i-a$
di-ñale $=$ pidana $]_{\mathrm{MC}} \|$
thus 3sGNF-do
little 3sGNF-overturn 3sGNF:go.up 3sGNF-go
3sGNF-disappear/die=REM.P.REP

'(As) he was doing thus, he almost overturned going upward (and) disappearing.'

[Tariana, Arawak; Aikhenvald, 2019, p. 462]

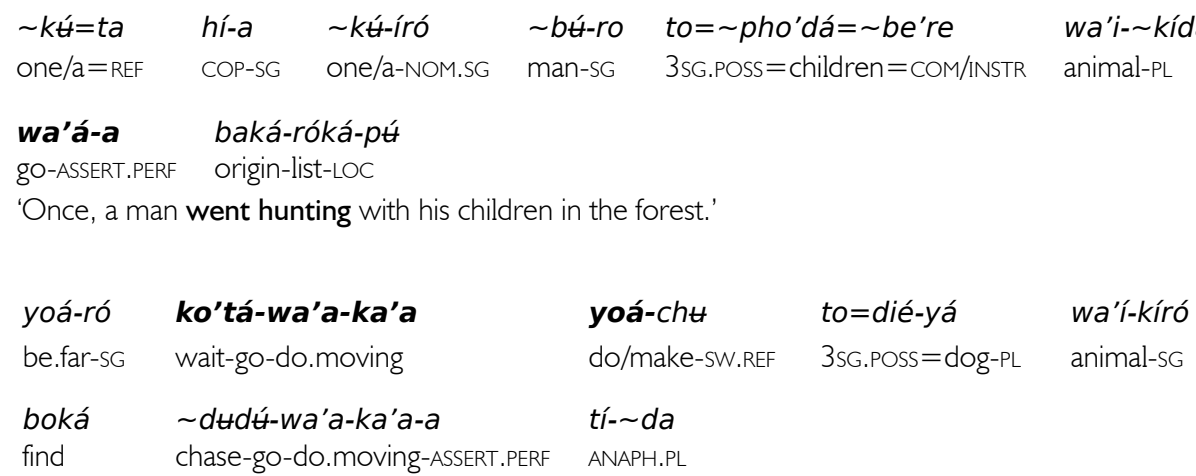

'(As/while they) went hunting farther away, his dogs found an animal (and) they went chasing after it.'

[Kotiria, East-Tukano; Stenzel, 2016, p. 438]

With respect to morphosyntactic properties, Guérin and Aiton (2019, p. 7) note that tail-clauses are typically expressed in declarative mood but mention some examples in which these can occur in non-declarative mood. This seems to be related to whether they appear as main clauses or dependent clauses; when tail-clauses are dependent clauses they are usually cast in declarative mood - a typologically common pattern (König \& Siemund, 2007, p. 285) - and when functioning as main clauses, there are usually no apparent restrictions (cf. Guérin \& Aiton, 2019, p. 7). While tail-clauses may be either main-clauses or dependent clauses, head-clauses in contrast are always dependent clauses presenting some sort of marking of syntactic dependency corresponding to language-internal processes of marking subordination (cf. Guérin \& Aiton, 2019, p. 8). ${ }^{7}$ As De Vries (2005) and Seifart (2010) point out, the morphosyntactic layout of tail-head linkage constructions corresponds to general characteristics of the respective language following strategies of basic clausal adjunction.

Likewise, scholars have also suggested correlations between the typological profile of languages and the occurrence of tail-head linkage. Consequently, tail-head linkage has often been described for more polysynthetic languages favoring null arguments and AOV languages among others (see De Vries, 2005; Seifart, 2010). However, recent descriptions of languages with distinct typological profiles, such as the examples from Guérin and Aiton's (2019) edited work or the case of Dâw as we will see here, show that languages with different profiles may also employ this strategy. For that reason, I agree with Guérin and Aiton (2019, p. 33) point to understand tail-head linkage not as an integral part of the grammar of languages, but as more of a stylistic device that manifests in discourse through grammar, thus functioning independently from a particular typological profile.

With respect to function, tail-head linkage strategies are predominantly employed in specific genres such as narratives and procedural texts in which they create cohesion in discourse (Seifart, 2010, pp. 894-895). Cohesion is understood as one of the fundamental properties of discourse (Wang \& Guo, 2014), and as ". . the interpretation of some element in the discourse is dependent on that of another" (Halliday \& Hasan, 1976, p. 4). Tail-head linkage constructions can then be

\footnotetext{
7 Stenzel (2016) shows for her data on Kotiria (East-Tukano) that some examples of tail-head linkage in this language can be understood as coordination from a syntactic perspective, however, are interpreted as subordination in the context.
}

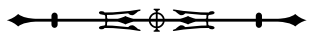


understood as structural organizing mechanisms that are responsible for cross-reference (Guérin \& Aiton, 2019, p. 25). For languages with a switch-reference system, tail-head linkage has been considered a straightforward strategy to track discourse participants, as shown in the Kotiria example above (see also Guillaume, 2011 for the Cavineña case).

Another well described function of this strategy is to guarantee thematic continuity through highlighting turning points or new events along the main event line (Guillaume, 2011, p. 112; Guérin \& Aiton, 2019, p. 26). This same function has also been referred to as the backgrounding or foregrounding of information (Stenzel, 2016, p. 437; Aikhenvald, 2019, p. 487). This is closely related to temporal sequentiality: by backgrounding one event and foregrounding a new event in the subsequent sentence, the storyteller strictly follows tense-iconic ordering of events along the narrative path. Some other semantic relations between paragraphs that can be triggered by tail-head linkage strategies are those of concession and consequence as described for Eibela (New Guinea); (see Aiton, 2019) or Aguaruna (Jivaroan family, Peru) (see Overall, 2017, pp. 499-502).

De Vries (2005, p. 378) mentions that tail-head linkage also has a listener-directed function to facilitate processing previously mentioned events. This observation resonates with my personal experiences transcribing and translating Dâw narratives together with a (usually) elder storyteller and a younger speaker. Whenever repetitions in the narratives appeared, the younger speaker, usually the transcriber, was tempted to not transcribe the repeated content again since 'this has already been said'. However, it was in these moments that the storyteller would intervene and insist that the repetition is important in order assure that the listener will be able to follow especially the spatial information repeated in the narrative.

Here, I understand tail-head linkages as syntactic strategies in which, minimally, the verbal predicate of a clause is repeated at the beginning of an adjacent complex clause. Tail-head linkages are thus a syntactic strategy motivated by the discursive need to establish coherence in specific discursive genres.

\section{THE DÂW PEOPLE AND THEIR LANGUAGE}

The Dâw language (Naduhup family), is currently spoken by only around 142 individuals in a single community called 'Waruá' located on the right riverbank of the Rio Negro in the municipality of São Gabriel da Cachoeira (Brazil, Amazonas). That region is known for its fascinating linguistic diversity, being the homeland of more than 24 different ethnic groups from five different language families (Naduhup, East-Tukano, Arawak, Kakua-Nikak, Yanomami) (see Epps \& Stenzel, 2013). Within the regional context, the Naduhup languages play an integral role in interactive regional networks, which link them to each other and to their river-dwelling horticulturalist neighbors. Speakers of all four groups of the Naduhup family have a hunting/gathering focus, in contrast to their more agriculture-oriented Arawak and Tukano neighbors.

The Dâw case is especially intriguing in this context, since this group migrated from the Middle Rio Negro region, considered Arawakan territory in the past, to the Upper Rio Negro region where they began to interact with Tukanonan groups, according to traditional Dâw narratives. Those interactions explain both Arawakan and Tukanoan traces in the Dâw lexicon and also provide clues with respect to Dâw's position within the Naduhup family. As Epps and Bolaños (2017) convincingly show, the Naduhup family is composed of the following four languages: Nadëb, Dâw, Yuhup and Hup. The current understanding of the family suggests that Nadëb is the first member to branch from the language family followed by Dâw and finally Hup and Yuhup. According to Epps and Obert (n.d.), this view on the classification supports that Proto-Naduhup originally developed in the Middle Rio Negro region followed by a migration to the west of the diverging groups, corresponding to their current distribution in the Upper Rio Negro region.

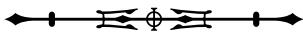


Dâw's intermediate position in the family tree is mirrored by the similarities of its typological profile with Hup and Yuhup, while shared lexical items explain its proximity to Nadëb. Dâw's phonological inventory is described by Martins (2004) as consisting of 25 consonants and 15 vowels. ${ }^{8}$ Dâw consonants are divided in glottalized sonorants and nonglottalized non-sonorants, and vowels can be oral or nasal, with exception of the low middle vowels (/o/, /e/ and $/ \gamma /$ ), which cannot be nasalized. Dâw is also a tonal language, with tone differentiating lexical items and having morphological functions.

With respect to its morphosyntactic profile, Dâw is an isolating language, with a few processes of suffixation and a preference for dependent marking. Many verbal categories and morphosyntactic processes are carried out through multiverbal constructions involving multiple distinct phonological words. The stringing of verbs in those constructions has been a productive source for the gramaticalization of verbal morphology in particular (see also Epps \& Anthanarayan, n.d.; Obert, 2020).

The basic constituent order in unmarked environments in Dâw is AVO/SV, with a degree of flexibility dependent on information structure (Epps, n.d.; Obert, 2019), which I will discuss in more detail in the following section when comparing the structure of main clauses and subordinate clauses. Dâw is also understood to have consistently nominative-accusative alignment that is morphologically visible on $\bigcirc$ arguments through the oblique case marker or

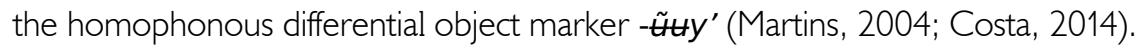

\section{MAIN CLAUSES AND SUBORDINATE CLAUSES IN DÂW}

This section provides a brief introduction to the morphosyntax of Dâw main clause structure as well as a general introduction to the main types of subordinate clauses in order to set the stage for the exploration of tail-head linkage strategies.

For this work, I understand a 'main clause' as an independent syntactic unit involving a predicate and its arguments. The verbal predicate of a main clause is inflected for all the language-internal required categories and has generally spoken a falling intonation (Fitzpatrick, 2000). 'Subordinate clauses or non-main clauses', in contrast, are unable to occur as independent utterances and therefore depend on another clause. This is understood as the syntactic process of subordination, in which two or more clauses combine so that one clause is a constituent (subordinate clause or dependent clause) of the other (main clause) (Thompson et al., 2007, p. 238; Van Gijn, 2011, p. 3). This syntactic dependency can surface in many aspects of grammar such as the morphosyntactic level; the degree of inflection in the verbal predicate (i.e. finite vs. non-finite) (cf. Guérin \& Aiton, 2019, p. 3); and also, through prosody (Mithun, 2005).

In Dâw, main clauses are headed by an uninflected verbal predicate whose arguments can be expressed by nominals being either full noun phrases (NP) or independent pronouns. Dâw's basic constituent order in unmarked contexts is SV (see ex. (5)) and AVO (see ex. (6)). In these clauses, the nominative-accusative alignment pattern surfaces by exhibiting core case-marking on pronominally expressed objects shown in (6), and otherwise occurs differentially as shown in (7) and (8), i.e. inanimate referents tend to be unmarked while +human nouns are marked through the

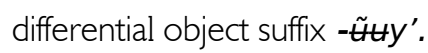

\footnotetext{
8 All examples in this work are displayed in Dâw's practical orthography showing the following phoneme-grapheme correspondences

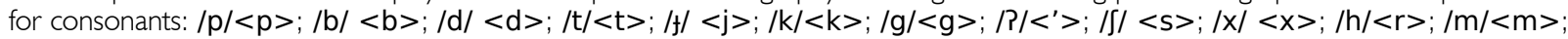

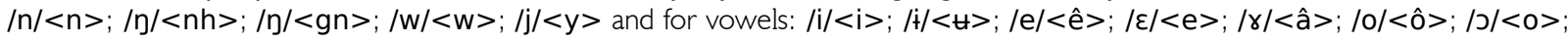
$|a|<a>$. Long vowels are marked in the orthography through doubled occurrence of the respective vowels.
}

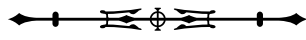


$\begin{array}{ll}\text { (5) } & \text { tir } \\ \text { 3sa } & \text { sleep } \\ \text { 'He sleeps.' }\end{array}$

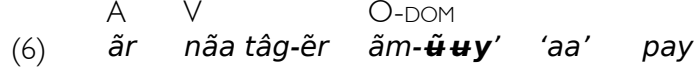

1sG talk HAB-NEG 2SG-DOM ANAPH like

'I never used to talk to you like this.'

(7) ãr paar kapawari xusee

1sG know kapawari.creek rapid

'I know the Kapawari rapids.'

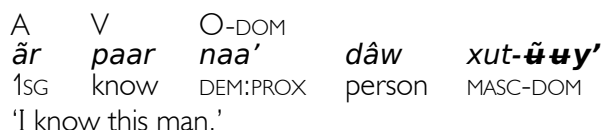

For ditransitive clauses Costa (2014, p. 184) reports that a homophonous form of the differential object suffix marks oblique constituents in order to disambiguate direct from indirect objects, as illustrated in (9).

\begin{tabular}{|c|c|c|c|c|c|}
\hline $\begin{array}{l}\text { A } \\
\text { dâw } \\
\text { person }\end{array}$ & $\begin{array}{l}\text { xut } \\
\text { MASC }\end{array}$ & $\begin{array}{l}V \\
\text { nõo } \\
\text { feed }\end{array}$ & $\begin{array}{l}\text { weed } \\
\text { food }\end{array}$ & $\begin{array}{l}\text { O-OBL } \\
\text { dâw } \\
\text { person }\end{array}$ & 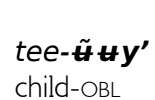 \\
\hline
\end{tabular}

Besides these preferred constituent ordering patterns, relative flexibility is observed, especially for transitive clauses which are sensitive to pragmatics in discourse where contrastive focus can be understood as the most important parameter (Obert, 2019; Epps, n.d.) (see example (10)). The inversion of constituents of Dâw intransitive clauses, in contrast, is not possible since this leads to distinct interpretations related to sentential mood. An inversion of $\mathrm{S}$ and $\mathrm{V}$ in the declarative clause from example (5) would result in interrogative mood as shown in (11). Only in focused contexts, in which $S$ is marked with the vowel-copying suffix $-V$ P, can it be found dislocated to post-verbal position without altering the sentential mood, as illustrated in example (12).

$\begin{array}{lllll}O & \mathrm{~A} & \vee & & \mathrm{OBL} \\ \text { kaswap } & i d & \text { nêe } & \text { ptn' } & \text { woor-ẽej } \\ \text { thing } & \text { 1PL } & \text { make } & \text { HAB } & \text { tukanoan.person-BEN }\end{array}$
'We did things for the Tukanoans.'

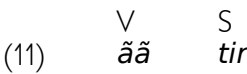

sleep 3sG

'Is he sleeping?'

$\begin{array}{lllll}\text { ADV } & V & & \text { S-FOC } & \text { ADV } \\ \text { diid } & \text { bax } & \text { koor } & \text { dâw-â' } & \text { primẽel } \\ \text { there:ITG } & \text { emerge } & \text { do.first } & \text { dâw.people-FOC } & \text { first } \\ \text { 'At first the Dâw people emerged there very far away.' }\end{array}$


Non-core participant roles in Dâw are indicated through a broad set of postpositions with an especially elaborated inventory of spatial postpositions marking locative adverbials (Obert, 2019). Non-core arguments frequently occupy the clause-final slot as exemplified in (9) or occur in clause-initial position in focused contexts, which will be discussed in detail in the following section.

Our understanding of subordination and, consequently, of the form of subordinate clauses in Dâw is still more limited than for simple clauses or processes of clause coordination, which are generally carried out via juxtaposition. One of the main reasons lies in Dâw's characteristic lack of morphology indicating finiteness or non-finiteness on verbs. A general indicator of dependency to a main clause is, however, the presence of clause-final subordinating elements in the dependent clause such as the relative marker 'pay' in (13). ${ }^{9}$ Grammaticality judgements by Dâw speakers provide further evidence that these clauses cannot stand alone when the main clause has not been uttered as shown in (14). Constituent order in subordinate clauses generally corresponds to the constituent order patterns described above, as the following examples will show.

$\begin{array}{llllll}{\left[\begin{array}{lll}\text { kas } & \text { puud } & \text { yêd }\end{array}\right]} & {[\text { laak }} & \text { âg } & \text { pay-a'] } \\ \text { be.ugly a.lot } & \text { INTS cachaça } & \text { drink } & \text { REL-FOC } \\ \text { 'Who drinks cachaça is really bad.' } & & \end{array}$

$$
\begin{array}{lll}
\text { *laak } & \text { âg } & \text { pay-a' } \\
\text { cachaça } & \text { drink } & \text { REL-FOC }
\end{array}
$$

In relative clauses, syntactic dependency is marked through the subordinators pay, as in (13) and (15), or uy, as in (16), which can relativize both core and non-core arguments. Relative clauses in Dâw can be headless and follow a gapping strategy, i.e., the relativized NP does not occur in the relative clause. When externally headed, they function as modifiers of a noun and occur in modifier position to the left of the head noun, as illustrated in (16).

$$
\begin{aligned}
& \text { [rid xâad-ẽr] [nũk war dâr weed pay] } \\
& \text { 3PL look.for-NEG ancient old PLZ eat REL }
\end{aligned}
$$

$$
\begin{aligned}
& \text { [tir âg xâjâa] [mẽenh nêe uy] suuk } \\
& \text { 3sG drink enter 1sG.POss make REL manioc.meal } \\
& \text { 'He entered drinking the (soaked) manioc meal that I made.' }
\end{aligned}
$$

\footnotetext{
9 Structures involving complementation differ from this pattern by 'not' showing a clause-final subordinating element. Complementation is then expressed through juxtaposition of a main clause and a dependent clause that functions as an object of the main clause, as shown in the example below. However, there is no morphological marking identifying syntactic dependency between the main and dependent clause. Consequently, whether these structures are best analyzed as subordinate or coordinate constructions is not clear and must be left for further research.
}

$\begin{array}{lllll}\text { [ãr } & \text { par] } & \text { [ãm } & \text { yũt } & \left.\text { 'yãm } x u^{\prime}\right] \\ \text { 1SG } & \text { know } & \text { 2sG } & \text { kill } & \text { jaguar }\end{array}$

'I know that you killed the jaguar.'

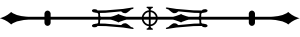


For subordinated adverbial clauses, Dâw also provides a diverse set of subordinators that occur in clause-final position in dependent clauses, establishing a semantic relationship with the main clause such as temporality (simultaneity/sequentiality), condition, purpose (as in example (17)), and location (as in example (18)) (see Martins, 2004, p. 495). I consider adverbial clauses in Dâw to be adjuncts since they can be omitted or substituted by a single word, and because they may modify either the verbal complex or the entire main clause. Their syntactic position with respect to the main clause is flexible and depends on their function in discourse, which I will address in more detail in the following section.

\begin{tabular}{|c|c|c|c|c|c|c|c|c|c|}
\hline $\begin{array}{l}\text { [dâw } \\
\text { person }\end{array}$ & $\begin{array}{l}\text { nãam } \\
\text { corpse }\end{array}$ & $\begin{array}{l}\text { tir } \\
3 \mathrm{sG}\end{array}$ & $\begin{array}{l}\text { yar } \\
\text { bring }\end{array}$ & $\begin{array}{l}\text { yâa } \\
\text { return }\end{array}$ & $\begin{array}{l}\text { mãr } \\
\text { RPT }\end{array}$ & $\begin{array}{l}\text { suub } \\
\text { Suub }\end{array}$ & $\begin{array}{l}\text { pej] } \\
\text { close.to }\end{array}$ & $\begin{array}{l}\text { [Suub } \\
\text { Suub }\end{array}$ & $\begin{array}{l}\text { weed } \\
\text { eat }\end{array}$ \\
\hline
\end{tabular}

$\begin{array}{llllll}\text { [dâw } & \text { bax } & \text { rid }] & {[\text { nũux }} & \text { nĩi } & \text { mãay } \\ \text { dâw.people } & \text { emerge } & \text { LOC } & \text { curupira } & \text { be.located } & \text { be.intensive }\end{array}$

'Where the Dâw people emerged, there were many curupiras (forest spirits).'

However, there are some cases in which adverbial clause constructions occur without any subordinating element, as illustrated in (19), where two clauses are found juxtaposed in order to provide a purposive reading. At first sight, this construction might be understood as coordination, however Dâw tends to delete co-referential arguments in coordination constructions, which is not the case in example (19). In contrast, when the co-referential argument is dropped as in (20), the relationship between the two clauses is one of coordination expressing the simultaneity of the two events expressed in both clauses.

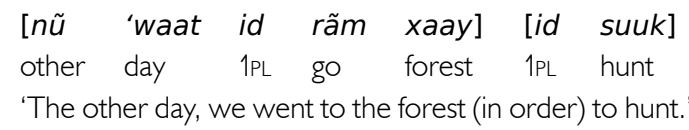

$\begin{array}{llllll}\text { [nũ 'waat } & \text { id } & \text { rãm xaay] [suuk] } \\ \text { other day } & \text { 1PL go forest hunt }\end{array}$

This brief introduction on the properties of Dâw's main clauses and subordinated clauses has shown that both clause types show many similarities regarding internal constituent order, showing the same alignment marking and the possibility of encoding tense-aspect-mood categories. I have shown that the main difference between these clause types lies in the presence of subordinating clause-final elements indicating syntactic dependency on a main clause. Having introduced the general characteristics of subordinate clauses in Dâw, we will now focus on locative adverbial clauses as the central element of tail-head linkage in Dâw.

\section{LOCATIVE ADVERBIAL CLAUSES IN DÂW}

This section focusses on the form and functions of locative adverbial clauses, as these are the structures repeated in tailhead linkages in Dâw narratives. I will first discuss their formal properties showing that these are instances of subordination and then examine their functions in discourse which vary with respect to their syntactic position in the main clause.

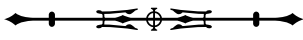


The previous section has shown how adverbial clauses exhibit similar properties compared to other types of subordination according to morphosyntactic properties in Dâw. Despite being subsumed as subordinating structures, the distinction from coordinating structures seems to be problematic especially for adverbial clauses, since they occupy an intermediate position on a continuum with coordinate clauses at one extreme and subordinate clauses at the other (see Lehmann, 1988). One reason for this is that adverbial clauses are considered to be a more hypotactic clause-combining strategy since they refer to the main clause as a whole (see Matthiessen \& Thompson, 1987), and can thus be understood as syntactically more adjoined rather than embedded (Van Gijn, 2011, p. 6). In comparison, relative clauses and complement clauses are considered to be more on the subordinating side of the continuum, as they are embedded structures (Thompson et al., 2007, p. 238). Another reason is that adverbial clauses are considered adjuncts, while complement clauses, for example, express core-arguments (see Diessel, 2013). Consequently, adverbial and relative clauses can be omitted, like coordinated clauses, whereas complement clauses cannot. However, adverbial clauses are usually marked by an adverbial subordinator that establishes a semantic relationship with the main clause (Diessel, 2013) and can also share other properties of subordinating structures such as specific verb forms, or different word order patterns (Thompson et al., 2007, p. 238). With these properties in mind, I summarize the following criteria of adverbial clauses in order to identify them in Dâw:

a) adverbial clauses appear with an adverbial subordinator establishing the semantic relationship to the main clause;

b) they are omittable, since they are adjuncts;

c) they can be replaced by a single adverb (in the case of time, manner and location adverbial clauses); and

d) they modify the verb of the main clause or the entire main clause.

Applying these criteria to example (21) below, which shows a prototypical locative adverbial clause construction in Dâw, we see the presence of the adverbial clause-final subordinating element rid. Locative adverbial clauses can also be marked by the interchangeable clause-final bug. As with other adverbial subordinators in Dâw, both have homonymous forms with spatial semantics providing evidence for diachronic development (Kortmann, 1997, p. 108). The subordinator rid, for example, is derived from the generic locative postposition taking nominal arguments, as illustrated in (22) (Obert, 2019, p. 85). ${ }^{10}$ However, in its function as a subordinator in locative adverbial clauses it is preceded by the clause in (21). The subordinator bug can both function as a spatial demonstrative adverb bug 'there' and also as a generic spatial postposition. Both rid and bug are interchangeable as subordinators, which may be derived from the fact that they are also interchangeable in their function as postpositions. Evidence for their usage as subordinators in adverbial clauses comes from restrictions on syntactic behavior. Without the main clause from example (21), the adverbial clause turns out to be ungrammatical as in (23), which shows syntactic dependency on the main clause.

$$
\begin{aligned}
& \text { tir rãm } \text { [rũur nĩi } \quad \text { rid ] } \\
& \text { 3sG go game be.located LOC } \\
& \text { 'He goes to (the place) } \text { where there is game.' }
\end{aligned}
$$

\footnotetext{
10 I understand the term 'generic spatial postposition' in opposition to a set of locative postpositions in Dâw, that express very specific topological relations. Both rid and $b u g$ indicate the generic location of a figure referent at a specific location without indicating a particular spatial relation between figure and ground.
}

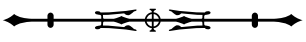


(22)

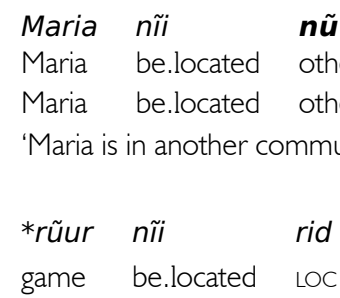

The criterion of omissibility is demonstrated in (23), i.e. the main clause from example (21) remains grammatical even when the adverbial clause is omitted. Finally, the adverbial clause can be replaced by a single word such as a spatial adverb like tiid 'thither' as shown in (24), proving again their status as adjuncts.

$$
\begin{aligned}
& \text { tir rãm tiid } \\
& \text { 3sG go thither } \\
& \text { 'He goes over there.' }
\end{aligned}
$$

Furthermore, in comparing examples (21) and (24), one can see that the adverbial clause modifies the main clause. Since the main clause predicate consists in the motion verb rãm 'go', the adverbial clause contributes the notion of goal of motion, i.e. the place where one can find game animals, entailing both telicity of the action and a physical endpoint of the motion event.

Similar to locative adverbial phrases, the function of locative adverbial clauses in Dâw is to indicate the ground that a figure referent relates to in a static or non-static spatial event. ${ }^{11}$ Locative adverbial clauses differ from locative adverbial phrases in that they do not express a prototypical landmark as the ground, but rather a place described by a specific 'event'. In (25), for example, the figure referent goes to the place where its owner previously went, or, in (26), to the place where a person used to kill alligators. This usage of locative adverbial clauses is a recurrent feature of Dâw discourse, since culturally important landmarks are very often referred to with the specific event that happened at those places.

$$
\begin{array}{llllll}
\text { 'aa' rãm }[\boldsymbol{d a ̂ w} & \text { tir } & \boldsymbol{d e e}^{\prime} & \text { rãm } & \text { rid }] \\
\text { ANAPH go dâw.people } 3 \mathrm{sG} \text { owner } & \text { gO } & \text { LOC } \\
\text { 'He went (to the place) where his owner went.' } &
\end{array}
$$

$$
\begin{aligned}
& \text { ãr rãm [ii' taa xeet yũt tâag rid] } \\
& \text { 1SG go father.vOC DSCD caiman kill HAB LOC } \\
& \text { 'I go (to the place) where my late father used to kill caimans.' }
\end{aligned}
$$

In the cases, in which the verbal predicate of the locative adverbial clause consists in the locative verb nii 'be located/existential', such as in example (27), these are interpreted by Dâw speakers as the figure being located in the closer surroundings of the abiu tree. When compared to grounds expressed by a postpositional phrase, speakers described the figure in (28) (he) as located exactly at the abiu tree. In other words, by choosing between a locative adverbial phrase and a locative adverbial clause consisting of the locative copula nĩi for the indication of the ground, Dâw speakers can alter the expression of the degree of proximity of a figure with respect to a specific ground.

\footnotetext{
11 I understand the terms 'figure' and 'ground' in the light of Talmy (2007) typology of motion events where he describes the 'figure' as the element to be sought in space, and the 'ground' as a kind of reference system describing the location of the figure. These terms correspond to what Langacker (1987) called 'trajector' and 'landmark'.
} 


$\begin{array}{lllll}\text { tir nĩ } & \text { [rõom } & \text { tâag } & \text { nĩi } & \text { rid] } \\ \text { 3sG be.located abiú } & \text { tree } & \text { be.located } & \text { LOC } \\ \text { 'He is (at the place) } & \text { where the abiu tree is.' } & \end{array}$

$\begin{array}{llll}\text { tir nĩ } & \text { rõom } & \text { tâag } & \text { rid } \\ \text { 3SG be.located abiú } & \text { tree } & \text { LOC } \\ \text { 'He is at the abiu tree.' } & & \end{array}$

From an intra-clausal perspective, we have seen that the main function of locative adverbial clauses is to indicate the ground of a spatial event, having a restricted scope in relation to the preceding main clause. On the discourse level, we can see that adverbial clauses have organizational functions and can be responsible for creating cohesion ( $\subset$. Thompson et al., 2007, p. 270; Guillaume, 2011, p. 110). According to these authors, this is directly related to their syntactic position with respect to the main clause, which is flexible in Dâw and can occur either postposed (29) or preposed (30c) to the main clause. Having in mind that the clause-initial slot is cross-linguistically understood as the locus of marking for discursive relations through, for example, conjunctions, we expect distinct functions of locative adverbial clauses in Dâw related to their syntactic position to the main clause they are dependent on.

\begin{tabular}{|c|c|c|c|c|}
\hline lâa & dôo' & [ãm & nîi-êe' & btg ] \\
\hline urn & & $2 s G$ & be.located-PST & LOC \\
\hline
\end{tabular}

$$
\begin{array}{llll}
\text { waa dâr bax tiid } & \ldots \\
\text { ancestor PLZ emerge thither } & \\
\text { 'The ancestors emerged there.' } & \text { [Line 1] }
\end{array}
$$

(30b) tiid bax mãr tiid wĩiç rid ... thither emerge RPT tither wĩiç.creek LOC 'They emerged there at the Wiiç river.' [Line 7]

$$
\begin{array}{llllll}
\text { [dâw } & \text { bax } & \text { rid] } & \text { nũux } & \text { nĩi } & \text { mãay } \\
\text { dâw.people } & \text { emerge } & \text { LOC } & \text { curupira } & \text { be.located } & \text { INTS } \\
\text { 'Where the Dâw people emerged, there were many curupiras (forest spirits).' [Line 12] }
\end{array}
$$

In example (29), the postposed adverbial clause appears to be closely related to the main clause, functioning as the linking element between the figure referent, typically the S/A argument of the main clause, and the ground expressed by the locative adverbial clause itself. However, when preposed as in (30c), the locative adverbial clause repeats spatial information establishing reference to information given earlier in the narrative, as illustrated in the examples in (30a-c), where the place of the Dâw people's emergence has been mentioned in the course of the narrative. ${ }^{12}$ In that sense, adverbial clauses in that position are topical, i.e. anchored in the preceding context. However, preposed adverbial clauses can also be understood as a form of index, introducing upcoming content that is related to that place, and fulfilling

\footnotetext{
12 Note that the examples in (30a-c) are selected lines from a single Dâw narrative. (30a) is the first line and (30b-c) are following lines with relevant spatial adverbial clauses. Lines between these examples were omitted for brevity and relevance.
}

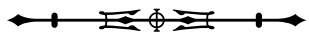


the function of "frame builders" (Charolles, 2005, p. 4). Charolles (2005, p. 4) points out that spatial and temporal adverbials are especially common as frame builders since it is easy for interlocutors to distinguish events when related to a particular spatial or temporal frame. Clause-initial adverbials can consequently have both backward-looking and forward-looking functions in discourse.

Figures 1 and 2 below illustrate the relations that locative adverbial clauses in Dâw can evoke with the main clause and with the discourse, depending on their syntactic position. This is central for our understanding of tail-head linkage strategies, once they consist of a unit of two complex clauses in which the first clause shows a postposed locative adverbial clause, while the following clause begins with the repetition of the exact same locative adverbial clause. In sum, Figure 1 shows that when the locative adverbial clause is postposed, its scope is restricted to the preceding main clause. Yet, when preposed, as schematized in Figure 2, the locative adverbial clause can modify the following main clause, establish reference to previously mentioned information, or introduce a new theme, i.e. a location, to which upcoming information can be related.

In describing the formal and functional properties of Dâw's locative adverbial clauses, I have provided evidence for syntactic dependency to a main clause which, in turn, leads us to assume that this type of complex clause is a form of subordination. Their main function is to represent grounds in spatial scenes that are comprised of an event functioning as a place reference, which is distinct from the function of adverbial phrases. To boot, I have shown that locative adverbial clauses in Dâw are a central resource for establishing cohesion in discourse, depending on their syntactic locus.

\section{TAIL-HEAD LINKAGE IN DÂW}

Earlier in this work, I described tail-head linkage as a syntactic strategy in discourse responsible for establishing coherence and which surfaces through the repetition of, minimally, the verbal predicate of a clause at the beginning of an adjacent complex clause. In this section, I will focus on the formal and functional properties of tail-head linkage in Dâw in order to show how spatial information can be tracked throughout narratives with the help of this strategy. Note that tail-head linkage in Dâw has been almost exclusively found in the repetition of spatial information in form of locative adverbial clauses, while authors usually describe this strategy for the repetition of any kind of information.

To begin with, I will first examine the layout of tail-head linkage constructions in Dâw based on the assumption that such a construction consists of two distinct discursive units, in which the 'tail-clause' is part of the first unit, while its replica, the 'head-clause' is part of the subsequent unit. The examples in (31a-b) illustrate two consecutive syntactic units which

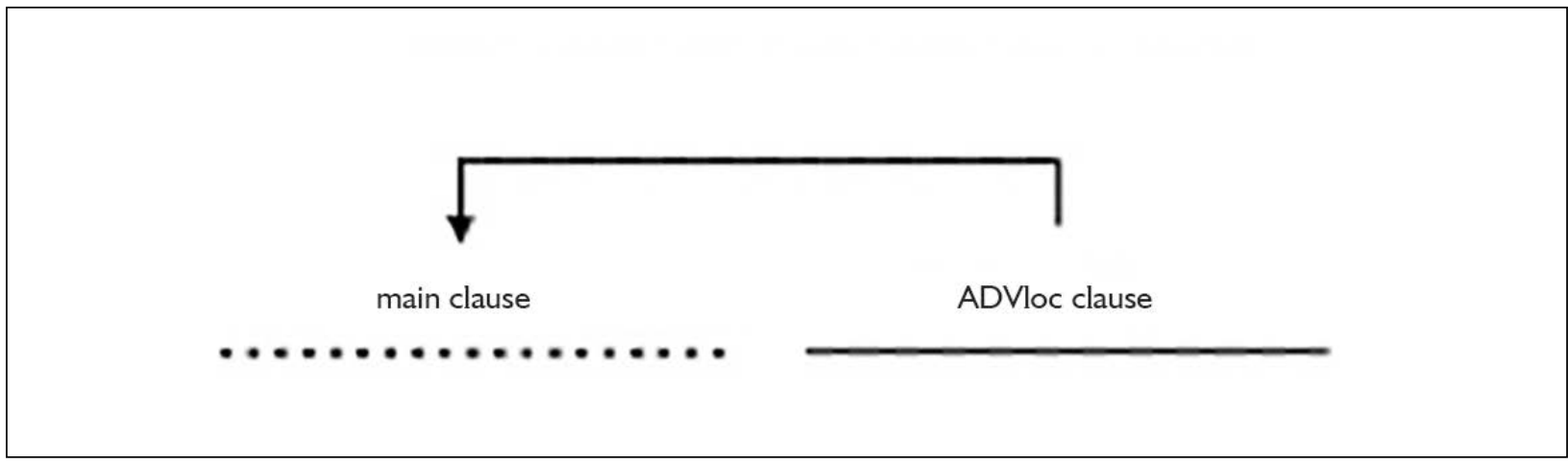

Figure 1. Main clause relationship of postposed adverbial clauses.

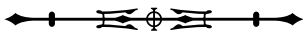




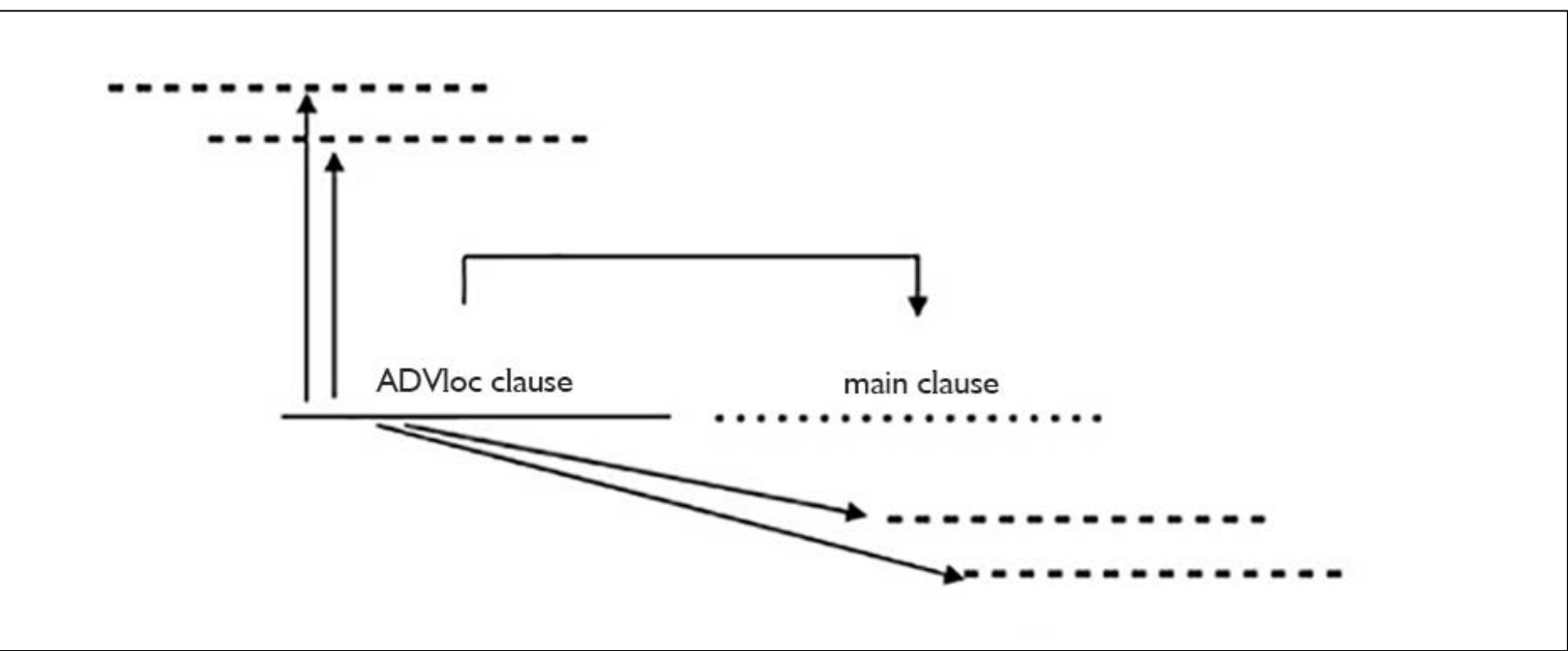

Figure 2. Relationship of preposed adverbial clause with main clause and discourse.

are each a complex clause consisting in a main clause and a subordinated locative adverbial clause (indicated in boldface). While in (31a) the locative adverbial clause follows the main clause, it is repeated at the beginning of the following complex clause. A close look at both locative adverbial clauses reveals that the head-clause is an exact replica of the tail-clause, repeating the verbal predicate, its arguments and also follows the same constituent order pattern.

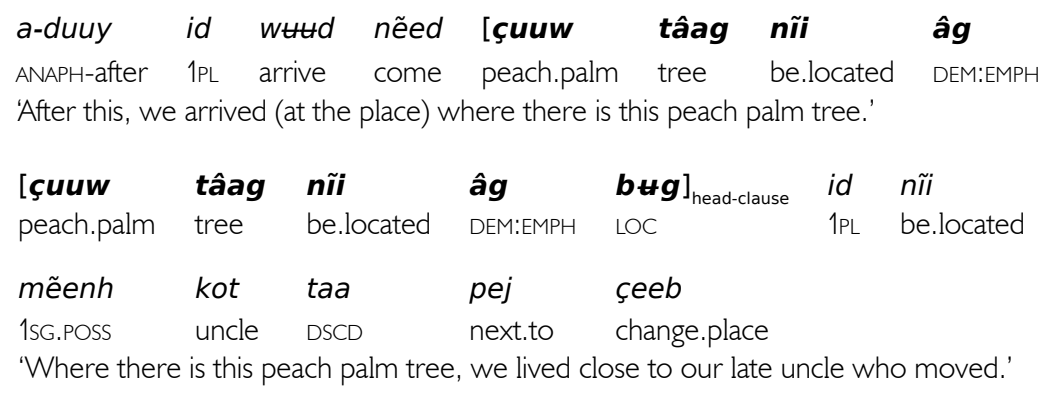

However, Dâw narratives also show examples of tail-head linkage in which the head-clause does not appear as a strictly verbatim repetition. For example, while the A argument in the tail-clause of (32a) is expressed by the full NP dâw 'Dâw people', it is found pronominalized (id '1PL') in the following head-clause. This has an effect on the semantic content of the head-clause, i.e. in this specific example the storyteller includes himself in the group of Dâw people who were engaged in resource extraction work. Additionally, lexical items can be either omitted or added. As Guérin and Aiton (2019, pp. 14-15) point out, omissions in these constructions frequently target arguments and adverbials, while additions are restricted to aspectual and lexical NPs, which are probably non-core arguments. As an illustration, we can see that the $\bigcirc$ argument (yum 'piaçava') from the tail-clause in (32a) has been omitted while the storyteller added an oblique argument (buuy rũuy 'with the white people') in the head-clause. Furthermore, the past tense suffix -êe' is not repeated in the head-clause, consistent with Dâw's characteristic lack of obligatory tense marking. Repeating the locative adverbial clause in the following discourse unit consequently allows the storyteller to add, omit or substitute information.

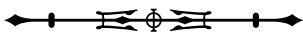


(32a)

\begin{tabular}{|c|c|c|c|c|c|c|c|c|}
\hline abug & xâd & $\begin{array}{l}\text { pee } \\
\text { go.upriver }\end{array}$ & $\begin{array}{l}\text { lab } \\
\text { Arabo.creek }\end{array}$ & $\begin{array}{l}\text { nõr, } \\
\text { mouth }\end{array}$ & $\begin{array}{l}\text { [dâw } \\
\text { dâw.people }\end{array}$ & $\begin{array}{l}\text { ‘wĩinh-êe’ } \\
\text { work-PST }\end{array}$ & $\begin{array}{l}\text { yum } \\
\text { piaçava }\end{array}$ & $\begin{array}{l}\boldsymbol{r i d}]_{\text {tail-clause }} \\
L O C\end{array}$ \\
\hline
\end{tabular}

'Then we went upriver to the Arabo creek, where the Dâw people worked with piaçava.'

\begin{tabular}{|c|c|c|c|c|c|}
\hline [id & ‘wĩinh & buuy & rũuy & rid $]_{\text {head-clause }}$ & $n \forall k e d e ̂ e^{\prime}$ \\
\hline 1PL & work & non.indigenous.person & SOC.COM & LOC & formerly \\
\hline id & $x u b$ & mĩi & nukedêe' & & \\
\hline 1PL & be.hungy & in.water & formerly & & \\
\hline
\end{tabular}

As both (31a-b) and (32a-b) show, tail-head linkage constructions in Dâw do not show a dedicated marker on the head clause indicating a relationship to the preceding discursive unit. Nevertheless, both tail and head clauses show the clause-final locative subordinators rid or bug discussed in the previous section, shedding light on the syntactic status of these clauses. Consequently, both tail- and head-clauses are not main clauses, and are best understood as subordinate clauses showing dependency with their preceding or following main clauses. Tail-head linkage constructions mirror the general strategy of dependency, that is, it is assigned to subordinated locative adverbial clauses in Dâw (Seifart, 2010, p. 898).

Structures mentioned earlier in this work as 'summary head linkage', which have been described for some of Dâw's neighboring languages (ex. Tariana) (see Aikhenvald, 2019); (ex. Kotiria) (see Stenzel, 2016) have not yet been attested in Dâw.

In the majority of Dâw tail-head linkage constructions, the repeated head clause appears immediately in the initial position of the adjacent sentence as (32a-b) above illustrated. However, there are some cases in which a clause can intervene between tail-clause and head-clause as illustrated in (33a-b). Note that both locative adverbial clauses in (33a) and (33b) are found in clause-initial position. I have frequently observed this specific form of repetition during more dialogical interactions in which community members are present during the act of storytelling and would occasionally echo some of the storyteller's utterances. The storyteller would then pick up the echoed utterance and repeat it again as presented in examples (33a-b). This form of structured dialogical interactions has been noted to be one of the most widespread areal features of discourse of the indigenous languages in Lowland South America and merits further exploration for the Dâw case (Beier et al., 2002, p.130).

\begin{tabular}{|c|c|c|c|c|c|c|c|}
\hline $\begin{array}{l}\text { [tiiid } \\
\text { thither }\end{array}$ & $\begin{array}{l}\text { dâw } \\
\text { dâw.people }\end{array}$ & $\begin{array}{l}\text { bax } \\
\text { emerge }\end{array}$ & $\begin{array}{l}\text { xoot } \\
\text { place }\end{array}$ & $\begin{array}{l}\text { rid] } \\
L O C\end{array}$ & $\begin{array}{l}\text { nũux } \\
\text { forest.spirit }\end{array}$ & $\begin{array}{l}\text { nĩ } \\
\text { be.located }\end{array}$ & mãay \\
\hline
\end{tabular}

\section{[dâw}
bax xoot rid] nũux
dâw-t̃uy'
'wuum dâr dâw.people emerge place LOC forest.spirit dâw.people-DOM drown PCTL '(At the place) where the Dâw people emerged, the curupira (forest spirit) drowned them.'

A prototypical tail-head linkage construction in Dâw primarily links clauses found at paragraph boundaries introducing a turn or a new event in the storyline that is then linked to the place expressed by the repeated locative adverbial clause. Accordingly, Dâw storytellers make use of this resource at the intersection of paragraphs, rather than at story

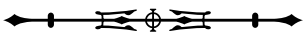


beginnings. Nevertheless, the onset of Dâw narratives commonly display place reference in locative constructions, which are entirely repeated in the consecutive line. Similar to tail-head linkage constructions described above, the constituent order of the repeated clause typically changes the position of the locative adjunct from clause final (34a) to clause-initial position as shown in (34a-b).

$\begin{array}{llllll}\text { (34a) tiid bax } \quad \text { mãr tiid wĩiç } & \text { rid } \\ \text { thither emerge } & \text { RPT thither } & \text { wĩç.creek } & \text { LOC } \\ \text { 'They emerged there at the Wilç river.' } & \end{array}$

\begin{tabular}{|c|c|c|c|c|}
\hline $\begin{array}{l}\text { wĩiç } \\
\text { Wiicç.creek }\end{array}$ & $\begin{array}{l}\text { rid } \\
\text { LOC }\end{array}$ & $\begin{array}{l}\text { dâw } \\
\text { dâw.people }\end{array}$ & $\begin{array}{l}\text { bax } \\
\text { emerge }\end{array}$ & $\begin{array}{l}\text { mãr } \\
\text { RPT }\end{array}$ \\
\hline
\end{tabular}

Clause-linking strategies such as tail-head linkage have been analyzed in the literature as marking semantic relations between discourse units (De Vries, 2005; Seifart, 2010; Guérin \& Aiton, 2019). Authors typically describe these constructions as indicating temporal relations between the discursive units but also meanings like concession (see Aiton, 2019) or consequence (see Overall, 2017). Since Dâw tail-head linkage constructions are restricted to the repetition of locative adverbial clauses, they undoubtedly provide continuities in spatial information across clauses. Differences can be observed with respect to static or non-static spatial events expressed in the main clause of the first discursive unit. For example, in both (31a-b) and (32a-b) above the main clauses of the (a) examples described a motion event, with the locative adverbial clause expressing the goal of the motion. The adjacent main clauses in the (b) examples express what happened at that specific place expressed by the same repeated adverbial clause. In other words, when motion events are involved in a tail-head linkage construction in Dâw, the goal of motion is invoked first and the event then unfolds at this particular goal. From a temporal perspective, this can be understood as iconic expression of the sequence of events: for example, arrival at place $X$ is followed by event $Y$ at place $X$. Tail-head linkage constructions showing static spatial scenes in the first discursive unit usually express the notion of two events happening simultaneously at the place expressed by the locative adverbial clause. This is illustrated in example (35a-b) where the storyteller first indicates the exact location of the first community she lived, a Tukanoan village, while in the subsequent clause she adds more detailed information to the description of the place, namely the existence of a river rapid close to the village. Again, a possible temporal reading between the clauses is a simultaneous one, rather than sequential.

\begin{tabular}{|c|c|c|c|c|c|c|c|}
\hline $\begin{array}{l}\text { primêl } \\
\text { first } \\
\text { first }\end{array}$ & $\begin{array}{l}\text { nir xoot } \\
\text { [be.located place] } \\
\text { village }\end{array}$ & $\begin{array}{l}\text { nẽb } \\
\text { Inebo.creek } \\
\text { Inebo.creek }\end{array}$ & $\begin{array}{l}\text { bug } \\
\text { there.DIST } \\
\text { there.DIST }\end{array}$ & $\begin{array}{l}\text { [woor } \\
\text { tukano.people } \\
\text { tukano.people }\end{array}$ & $\begin{array}{l}\text { nir xoot } \\
\text { [be.located place }] \\
\text { village }\end{array}$ & $\begin{array}{l}\text { nĩ } \\
\text { be.located } \\
\text { be.located }\end{array}$ & $\begin{array}{l}\text { rid }]_{\text {tail-clause }} \\
L O C \\
L O C\end{array}$ \\
\hline
\end{tabular}

$\begin{array}{llllllll}\text { [woor } & \text { nir xoot } & \text { nĩi } & \text { rid] }]_{\text {head-clause }} & \text { nĩi } & \text { nâax } & \text { xusee } & \text { dũ' } \\ \text { tukano.people } & \text { be.located place] } & \text { be.located } & L O C & \text { be.located } & \text { water } & \text { rapid } & \text { also } \\ \text { tukano.people } & \text { village } & \text { be.located } & L O C & \text { be.located } & \text { water } & \text { rapid } & \text { also } \\ \text { 'Where there Tukanoan village is, there is also a river rapid.' } & & & & \end{array}$

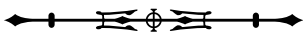


These observations bring us a step closer to considering the discourse functions of tail-head linkages in Dâw. What we have just described above can be subsumed as topic shifting once a new topic is introduced after the head clause. The function of the repeated locative adverbial clause, then, is to closely connect two distinct events to the exact same place, as schematized in Figure 3 below. This corresponds to what was observed in above for the syntactic positions of adverbial clauses and their related functions (see Figures 1 and 2 above). The postposed adverbial clause in the first discursive unit indicates the ground of the event denoted by the main clause. When preposed in the following discursive unit, the repeated locative adverbial clause establishes a direct reference to the previously mentioned event and introduces a new theme. In this position, upcoming events in discourse can then again be related to the place expressed by the preposed locative adverbial clause. The repetition of a locative adverbial clause in these constructions functions as the key element for connecting two events to the exact same location. Topic shifting is consequently one of the central functions of tail-head linkage constructions in Dâw narratives and is a cohesive technique that facilitates the addition of a new event to the main story line.

This cohesive function is closely related to the function of structuring discourse in Dâw; i.e. tail-head linkage constructions appear on the boundaries between episodes expressed in paragraphs in line with Longacre (1983, p. 9), or as an indicator of a new paragraph, as noted by Guérin and Aiton (2019, p. 27). The presence of tail-head linkage constructions at the intersection of paragraphs is responsible for the transitions between main events and has, at the

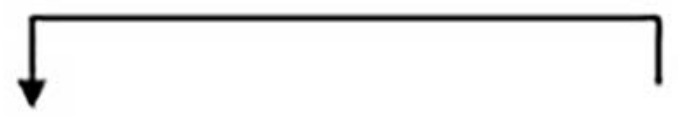

main clause

ADVloc clause

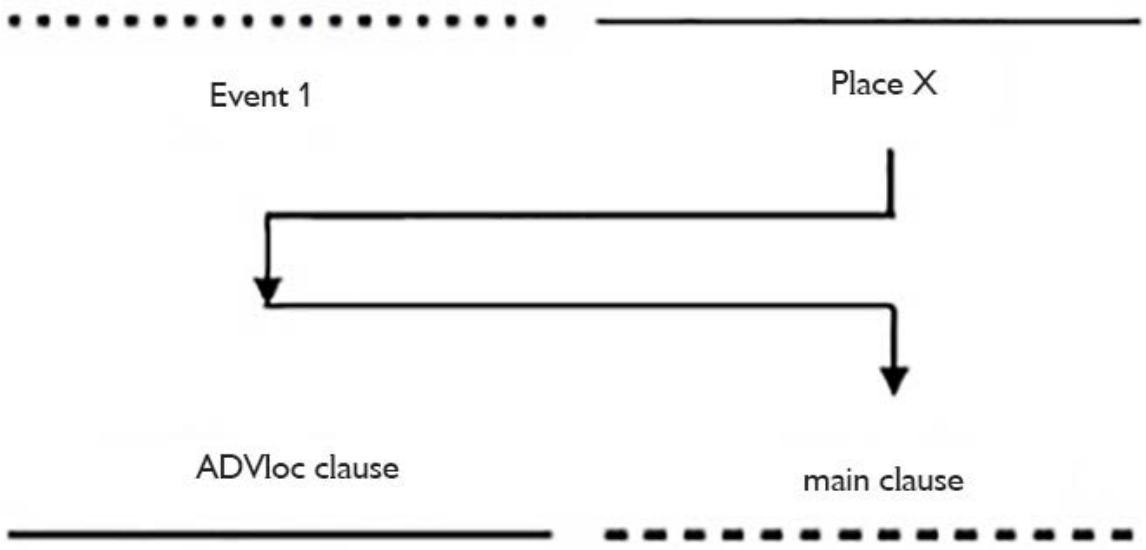

Place X

Event 2

Figure 3. Scheme of tail-head linkage construction in Dâw.

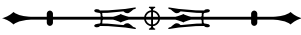


same time, a linking function. In his work on Siroi tail-head linkage constructions, Van Kleef (1988, p. 153) states that “. . . by just glancing over the recapitulated clauses [i.e. head-clauses] of a story you can usually get an accurate impression of the story line." since these repetitions signal the most important events of the story. This resonates partially with our observations for the Dâw case, since tail-head linkage constructions clearly indicate here the transition between key events in a narrative. However, in the Dâw case, it is 'not' the repeated locative adverbial head-clauses that should be conceived as main events, but the two distinct events that happen at the same place indicated by the tail and the head clauses. As a consequence, I argue that repeated place reference through these constructions can be analyzed as an indicator or even as an instrument for signaling the beginning of a new event or turn.

Tail-head linkage constructions are similar to other structures of repetition in Dâw narratives involving other types of locative adjuncts such as postpostional phrases as illustrated in (34a-b) or bare NPs indicating a place reference as in (36a-b). They follow the pattern observed for tail-head linkage as the locative adjunct appears in clause-final position and is repeated in clause-initial position in the subsequent clause. Interestingly, in contrast to tail-head linkage constructions, these can be found at the onset of the narrative. A possible reason is that Dâw storytellers usually begin a narrative by setting the stage mentioning a place reference, which is either a landmark or a place name. Then, as the story unfolds, places frequently turn in to locations of events, which are then expressed by locative adverbial clauses in tail-head linkage constructions.

$\begin{array}{llll}\text { nukêdêe' } & \text { id } & \text { pêg } & \text { xaay } \\ \text { formerly } & \text { 1PL } & \text { be.big } & \text { forest } \\ \text { 'In the old days, we were raised in the forest.' }\end{array}$

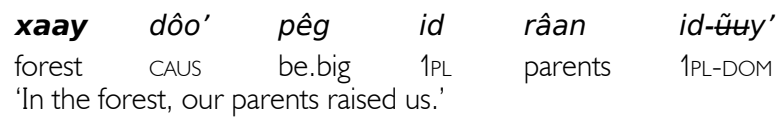

According to De Vries (2005, p. 378) another function of tail-head linkage is to help the storyteller to plan the narration and to elaborate the following part of the narrative. From another perspective, it helps the listener to process previous events. This is in line with experienced Dâw storytellers, who describe the emphasis of place reference through several structures in narratives as a strategy for preventing the listener from "getting lost in the story and in the forest" (D. Fernandes, personal communication, June 7, 2018). ${ }^{13}$

As the examples of this section show, tail-head linkage strategies are very frequent in narratives addressing the time of the Dâw people's migration from the Middle Rio Negro region to the Upper Negro region. This is a core reason that we consider the key events of these stories to be linked to very specific places and events that happened at those places in the Dâw people's traditional territory. Likewise, personal stories with biographical information frequently involve information of the person's spatial mobility in the past until arriving at their current village of residence. Spatial dislocation and the establishment of constant reference to these places are therefore central features of traditional Dâw narratives, which are realized through syntactic devices such as tail-head linkage. This resembles the phenomenon of 'echoing' what Guillaume (2016, p. 91) describes for associated motion constructions, in which the juxtaposition of a motion verb and a semantically similar associated motion marker functions as a foregrounding device.

\footnotetext{
${ }^{13}$ Elder speaker of Dâw.
}

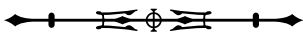




\section{CONCLUSION}

This work has discussed the form and functions of tail-head linkage in Dâw narratives - a syntactic strategy which is deployed for the specific discursive purpose of tracking spatial information. We first explored this strategy from a typological perspective in order to identify its main characteristics, and examined processes of subordination with an emphasis on locative adverbial clauses in Dâw, as they are the core element of Dâw tail-head linkage constructions. As a result, I provided evidence that tail-head linkage constructions in this language broadly correspond to the existing understanding of formal properties from a cross-linguistic perspective, since they show the repetition of at least the verbal predicate from the tail clause in the head clause; they appear predominantly in adjacent position; they can show flexibility with respect to the repetition of core and non-core arguments or other lexical elements; and the head clause (as well as the tail clause) is a subordinated clause. Likewise, their functions correspond broadly to what has been described for other languages, namely the creation of cohesion and the structuring of discourse.

They also deviate from the existing cross-linguistic observations in that Dâw tail-head linkage constructions are mostly restricted to locative adverbial clauses. While other languages can repeat main clauses or any other type of adverbial information in the head-clause, as shown in examples (1a-b) through (3a-b), this has not been attested in Dâw. This provides interesting clues to their functional properties, and more specifically to what has been described for tailhead linkage and its relation to main events. While authors broadly agree that the repeated clauses, i.e. head clauses, can be understood as expressing the main events in a storyline, in Dâw these express locative adverbial information. In addition, I have shown that these constructions occur at paragraph boundaries and have a topic shifting function. In other words, tail-head linkage constructions in Dâw link two main events at one and the same place represented by the repeated locative adverbial clause. The repeated locative adverbial clause in the two discursive units is then best understood as a mechanism of pointing back and looking forward, departing from a specific place reference established by the locative adverbial clause. In other words, the locative adverbial clause functions as a spatial anchor or a pinpoint on a mental map of the Dâw people's territory at which two distinct events can take place. Glancing over the repeated locative adverbial clauses throughout a Dâw narrative can be compared to the function of a compass guiding both storyteller and listener through the narrative, corresponding to the phenomenon of echoing.

Furthermore, this work has shed some light on processes of adverbial subordination in Dâw that are still not fully understood in the context of Dâw syntax as a whole. Additionally, it has provided evidence for how clause-level phenomena are crucial to the understanding of discourse structure and techniques for textual cohesion. I finally agree with Guérin and Aiton (2019, p. 33) understanding of tail-head linkage as a stylistic device that can be used in narratives, regardless of the typological profile of the language, rather than understanding it as a part of the grammar of a language. The Dâw case additionally provides support to the notion that tail-head linkage strategies mirror language-internal mechanisms of subordination, i.e. being marked by a clause-final subordinating element.

In conclusion, we have seen that discursive strategies in Dâw narratives correspond to the need for the transmission of spatial knowledge across generations. This communicative need for emphasizing spatial information suggests a connection to their spatial mobility and their intimate interaction with the forest, which requires a high degree of awareness with respect to spatial orientation, specific wayfinding strategies, and, as a consequence, adapted communicative and discursive strategies (O'Meara et al., 2020, p. 295). In sum, this work provided evidence that our understanding of the linguistic encoding of space in grammars of the world's languages can go beyond clause-level and can be used to structure discourse.

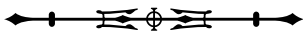




\section{ACKNOWLEDGEMENTS}

I am deeply grateful for the collaboration and friendship of Dâw people who welcomed me in their community and land, and for sharing their knowledge with me. I also thank the Museu Paraense Emílio Goeldi (MPEG), Fundação Nacional do Índio (FUNAI), Federação das Organizações Indígenas do Rio Negro (FOIRN), and Associação das Comunidades Indígenas do Médio Rio Negro (ACIMRN) for permission and sponsorship for work in Brazil. I also gratefully acknowledge my funders NEH; University of Texas at Austin; the University of São Paulo and the Firebird Foundation. Further thanks go to my colleagues and their valuable contributions to this paper: Pattie Epps, Kelsey Neely, Luciana Storto and the audience of the session "Complex structures in Brazilian languages" organized by Suzi Lima and Tonjes Veenstra at ABRALIN (2019). Finally, I thank the reviewers of this paper for their insightful comments on this paper.

\section{ABBREVIATIONS}

$\begin{array}{llll}1 & \text { first person } & \text { ITG } & \text { intangible } \\ 2 & \text { second person } & \text { MASC } & \text { masculine } \\ 3 & \text { third person } & \text { MC } & \text { main clause } \\ \text { A } & \text { agent } & \text { NEG } & \text { negation } \\ \text { ADV } & \text { adverbial } & \text { NF } & \text { non-feminine } \\ \text { AGTV } & \text { agentive } & \text { NOM } & \text { nominative } \\ \text { ANAPH } & \text { anaphoric } & \text { O } & \text { object } \\ \text { ASSERT } & \text { assertion } & \text { OBL } & \text { oblique } \\ \text { AUG } & \text { augmenative } & \text { PCTL } & \text { punctual } \\ \text { AUX:DIR } & \text { directional auxiliary } & \text { PERF } & \text { perfective } \\ \text { BEN } & \text { benefactive } & \text { PL } & \text { plural } \\ \text { CAUS } & \text { causative } & \text { PLZ } & \text { pluralizer } \\ \text { CL } & \text { classifier } & \text { PRS } & \text { present } \\ \text { COM } & \text { comitative } & \text { PST } & \text { past } \\ \text { CONN } & \text { connective } & \text { POSS } & \text { possessive } \\ \text { COP } & \text { copula } & \text { REF } & \text { referential } \\ \text { DEM:EMPH } & \text { emphatic demonstrative } & \text { REL } & \text { relativizer } \\ \text { DEM:PROX } & \text { proximate demonstrative } & \text { REM.P.REP } & \text { remote past reported } \\ \text { DIST } & \text { distal } & \text { RPT } & \text { reportative } \\ \text { DOM } & \text { differential object marker } & \text { S } & \text { subject } \\ \text { DSCD } & \text { deceased marker } & \text { SG } & \text { singular } \\ \text { FNL } & \text { final } & \text { SOC.COM } & \text { social comitative } \\ \text { FOC } & \text { focus } & \text { SS } & \text { same subject } \\ \text { LOC } & \text { locative } & \text { SW.REF } & \text { switch reference } \\ \text { HAB } & \text { habitual } & \text { V } & \text { verb } \\ \text { INSTR } & \text { instrumental } & & \text { vocative } \\ \text { INTS } & \text { intensifier } & & \\ & & \text { VOC } & \end{array}$

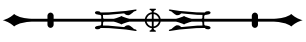




\section{REFERENCES}

Aikhenvald, A. Y. (2019). Bridging linkage in Tariana, An Arawak language from Northwest Amazonia. International journal of American Linguistics, 85(4), 455-496.

Aiton, G. (2019). The form and function of bridging constructions in Eibela discourse. In V. Guérin (Ed.), Bridging constructions (pp. 157185). Language Science Press.

Beier, C., Michael, L., \& Sherzer, J. (2002). Discourse forms and processes in indigenous lowland south America: An Areal-Typological perspective. Annual Review of Anthropology, 31, 121-145. https://doi.org/10.1146/annurev.anthro.31.032902.105935

Chafe, W. (2001). The analysis of discourse flow. In D. Schiffrin, D. Tannen \& H. E. Hamilton (Eds.), The handbook of discourse analysis (pp. 673-687). Blackwell.

Charolles, M. (2005, january). Framing adverbials and their role in discourse cohesion from connection to forward labelling. Papers of the Symposium on the Exploration and Modelling of Meaning.

Costa, J. C. (2014). A estrutrua argumental da língua Dâw [Tesis de maestría, Universidade de São Paulo, São Paulo].

De Vries, L. (2005). Towards a typology of tail-head linkage in Papuan languages. Studies in Language, 29(2), $363-384$.

Diessel, H. (2013). Adverbial subordination. In S. Luraghi \& C. Parodi (Orgs.), Bloomsbury Companion to Syntax (pp. 341-354). Continuum.

Dingemanse, M., Rossi, G., \& Floyd, S. (2017). Place reference in story beginnings: A cross-linguistic study of narrative and interactional affordances. Language in Society, 46, 129-158. http://doi.org/10.1017/S0047404516001019

Epps, P., \& Stenzel, K. (2013). Upper Rio Negro: Cultural and linguistic interaction in northwestern Amazonia. Museu do Índio.

Epps, P., \& Bolaños, K. (2017). Reconsidering the "Makú" language family of northwest Amazonia. International Journal of American Linguistics, 83(3), 467-507. https://doi.org/10.1086/691586

Epps, P., \& Obert, C. (n.d.). Linguistic clues to hunter-gatherer histories: The Naduhup peoples of northwest Amazonia. Manuscript submitted for publication.

Epps, P. (n.d.). Naduhup. In P. Epps \& L. Michael (Orgs.), Handbook of Amazonian languages (Vols. 1-2, Amazonian languages: Families and isolates). De Gruyter Mouton.

Epps, P., \& Ananthanarayan, S. (n.d.). Stability in grammatical morphology: An Amazonian case study. In P. Epps, D. Law \& N. Pat-El (Orgs.), Historical linguistics and endangered languages: Exploring diversity in language change (Routledge Series in Historical Linguistics). Routledge.

Fitzpatrick, J. (2000). On intonational typology. STUF: Language Typology and Universals, 53(1), 88-96. https://doi.org/10.1524/stuf.2000.53.1.88

Grimes, J. (1972). Outlines and Overlays. Language, 48(3), 513-524.

Guérin, V., \& Aiton, G. (2019). Bridging constructions in typological perspective. In V. Guérin (Ed.), Bridging constructions (pp. 1-45). Language Science Press.

Guillaume, A. (2011). Subordinate clauses, switch-reference, and tail-head linkage in Cavineña narratives. In R. Gijn, K. Haude \& P. Muysken (Orgs.), Subordination in Native South American Languages (pp. 109-139). John Benjamins Publishing Company.

Guillaume, A. (2016). Associated motion in South America: Typological and areal perspectives. Linguistic Typology, 20(1), 81-177. https:// doi.org/10.1515/lingty-2016-0003

Halliday, M., \& Hasan, R. (1976). Cohesion in English. Longman.

König, E., \& Siemund, P. (2007). Speech act distinctions in grammar. In T. Shopen (Org.), Language typology and syntactic description (2 ed., Vol. 1, Clause Structure, pp. 276-323). Cambridge University Press.

Kortmann, B. (1997). Adverbial subordination: A typology and history of adverbial subordinators based on European Languages. Mouton de Gruyter.

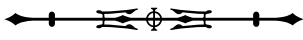


Langacker, R. W. (1987). Foundations of cognitive grammar (Vol. 1, Theoretical perspectives). Stanford University Press.

Lehmann, C. (1988). Towards a typology of clause linkage. In J. Haiman \& S. A. Thompson (Orgs.), Clause combining in grammar and discourse (pp. 181-226). John Benjamins.

Longacre, R. E. (1968). Philippine languages: Discourse, paragraph and sentence structure (Vol. 21). Publications in Linguistics \& Related Fields. SIL.

Longacre, R. E. (1983). The grammar of discourse. Plenum Press.

Martins, S. (2004). Fonologia e Gramática Dâw. LOT.

Matthiessen, C., \& Thompson, S. A. (1987). The structure of discourse and subordination. In J. Haiman \& S. A. Thompson (Orgs.), Clause combining in grammar and discourse (pp. 275-330). John Benjamins.

McKay, G. (2008). Cohesive features in Rembarrnga narratives. In T. Curnow (Org.), Selected papers from the 2007 Conference of the Australian Linguistic Society (17 p.). Australian Linguistc Society.

Mithun, M. (2005). Re(e)volving complexity: Adding intonation. In T. Givón \& M. Shibatani (Eds.), Syntactic complexity: Diachrony, acquisition, neuro-cognition, evolution (pp. 53-80). John Benjamins.

Obert, K., Marques, M. M., Sousa, P. M., Castro, M. A. S., \& Castro, N. S. C. (2019). Waa dâr tuuw. Revista Linguística, 15(1), $175-211$. http://dx.doi.org/10.31513/linguistica.2019.v15n1a25566

Obert, K. (2019). The Linguistic encoding of space in Dâw [Doctoral dissertation, Universidade de São Paulo, São Paulo].

Obert, K. (2020). Complex predicates and space in Dâw (Naduhup language, AM). STUF - Language Typology and Universals, 73(1), 27-55. https://doi.org/10.1515/stuf-2019-0026

O'Meara, C., Burenhult, N., Rothstein, M., \& Sercombe, P. G. (2020). Representing space and place: Hunter-gatherer perspectives. Hunter Gatherer Research, 4(3), 287-309. http://dx.doi.org/10.3828/hgr.2018.19

Overall, S. E. (2017). A grammar of Aguaruna. Mouton de Gruyter.

Pensalfini, R. (2015, February 24-25). Canonical and non-canonical bridging constructions in Jingulu [Paper presented at: The special workshop of the Language and Culture Research Centre entitled].

Seifart, F. (2010). The Bora connector pronoun and tail-head linkage: A study in language-specific grammaticalization. Linguistics, 48(2), 893-918. https://doi.org/10.1515/ling.2010.028

Sherzer, J. (1987). A discourse-centered approach to language and culture. American Anthropologist, 89(2), 295-309.

Stenzel, K. (2016). More on switch-reference in Kotiria (Wanano, East Tukano). In R. Van Gijn \& J. Hammond (Orgs.), Switch reference 2.0 (Typological Studies in Language, No. 114, pp. 425-452). John Benjamins.

Stenzel, K., \& Franchetto, B. (2017). Amazonian narrative verbal arts and typological gems. In Author (Eds.), On this and other worlds: Voices from Amazonia (pp. 1-22). Language Science Press.

Stout, M., \& Thomson, R. (1971). Kayapó narrative. International Journal of American Linguistics, 37(4), $250-256$.

Sugiyama, M. S. (2001). Food, foragers and folklore: The role of narrative in human subsistence. Evolution and Human Behavior, 22(4), 221-240. https://doi.org/10.1016/S1090-5138(01)00063-0

Talmy, L. (2007). Lexical typologies. In T. Shopen (Org.), Language typology and syntactic description (2nd ed., Vol. 3, pp. 66-168). Cambridge University Press.

The Archive of the Indigenous Languages of Latin America. (n.d.). Dâw language collection. https://bit.ly/2OIL106

Thompson, S., Longacre, R., \& Hwang, S. (2007). Adverbial clauses. In T. Shopen (Org.), Language typology and syntactic description (Vol. 2, pp. 237-300). Cambridge University Press.

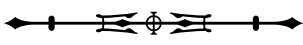


Van Gijn, R. (2011). Semantic and grammatical integration in Yurakaré subordination. In K. Haude, R. Van Gijn \& P. Muysken (Orgs.), Subordination in Native South American Languages (pp. 169-192). John Benjamins.

Van Kleef, S. (1988). Tail-head linkage in Siroi. Language and Linguistics in Melanesia, 20, 147-156.

Wang, Y., \& Guo, M. (2014). A short analysis of discourse coherence. Journal of Language Teaching and Research, 5(2), 460-465. http://doi. org/10.4304/jtr.5.2.460-465 